\title{
USING GIS AND AHP FOR PLANNING PRIMER TRANSPORTATION OF FOREST PRODUCTS
}

\author{
A. E. Akay ${ }^{1, *}$, B. Y1lmaz ${ }^{1}$ \\ ${ }^{1}$ Forest Engineering Department, Faculty of Forestry, Bursa Technical University - 16310 Yıldırım Bursa, Turkey - (abdullah.akay, \\ basak.yilmaz)@btu.edu.tr
}

KEY WORDS: Forest Transportation, GIS, AHP, Decision Support System

\begin{abstract}
:
Primer transportation is one of the most costly and time consuming forestry activities in extraction of timber from forest lands. Transportation methods are essentially determined based on terrain characteristics, especially ground slope. Besides, unsuitable machine selection and unplanned operations may cause ecological damages such as soil disturbance. Soil damage can lead to long term impacts on forest ecosystem. Thus, the optimum transportation methods should be determined by considering not only economic factors but also topographical factors and soil conditions. In recent decades, some of the advanced features of Geographical Information System (GIS) assist decision makers to solve such complex transportation problems with various constraints. In this study, it was aimed to plan forest transportation operation by using GIS integrated Analytical Hierarchy Process (AHP) method, considering ground slope, soil type, and available transportation equipment in the region. This method was implemented within the border of İnegöl Forest Enterprise Chief in the city of Bursa in Turkey. Alternative transportation method included cable system, chute system, skidder, and farm tractor. GIS-based method integrated with AHP found that skidder was the optimal transportation method for about $60 \%$ of the study area, while farm tractor was the second most suitable method with $25 \%$ ground cover. The results indicated that GIS-based decision support systems can be effectively used as rational, quick, and economic tool for forest transportation planning.
\end{abstract}

\section{INTRODUCTION}

Timber extraction from stump to landing areas at roadside can be defined as primer transportation of forest products. Primer transportation can be very costly and time consuming activity when transportation methods are not planned in the office or not properly implemented in the field. Primer transportation cost increases in forested areas with difficult terrain conditions where the amount of road network is not sufficient. Besides, unplanned timber extraction may result in serious ecological damages on resıdual trees and forest soil (Akay and Erdaş, 2007; Y1lmaz and Akay, 2008). In order to minimize these potential damages and ensure sustainability of forest ecosystem, primer transportation activities should be well planned by considering economic and ecological factors.

In forest transportation activities, conventional methods with little or no mechanization involvement are used in many parts of Turkey. The mechanized transportation methods are mostly implemented by using modified farm tractors during skidding operations (Figure 1). These farm tractors are improved by $4 \mathrm{x} 4$ drive feature, equal loads on both axles, and protected driver cabin (Öztürk and Akay, 2007). Farm tractors are limited by the ground slope of up to $33 \%$ (Gülci, 2014). In recent years, skidders, which are specifically designed and manufactured for primer transportation of forest products, have been used by few logging companies in Turkey (Akay et al., 2016). The forest products are skidded by using chains or grapples attached to the skidders that can operate up to $40 \%$ slope (Akay and Yenilmez, 2008). On steeper grounds, forest products are transported from the woods by using a cable system that is strung in corridors through the forest. In Turkey, cable systems are used mostly in northeast part of Turkey where forests are located on steep grounds (Türk, 2011). For the forested areas where skidding operations are not preferred and cable system is not available, downhill sliding of logs within plastic chute systems by gravity is preferred at the slope of $20-60 \%$ in Turkey (Çankal, 2013; Gülci et al., 2016). Chute system potentially reduces production cost, minimizes stand damage, and prevents value loss of wood products.

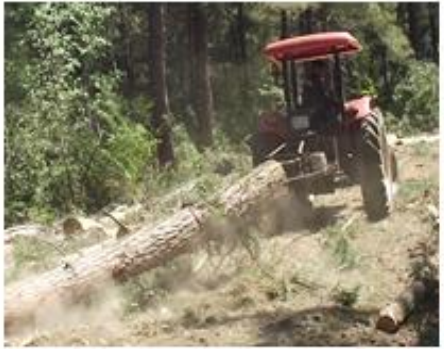

(a)

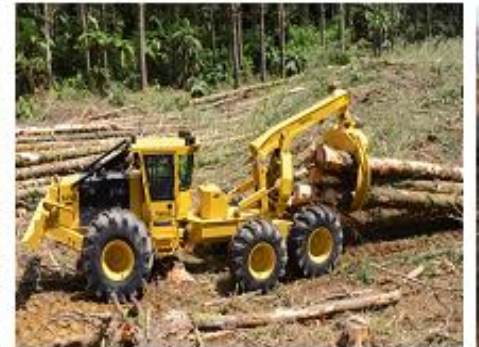

(b)

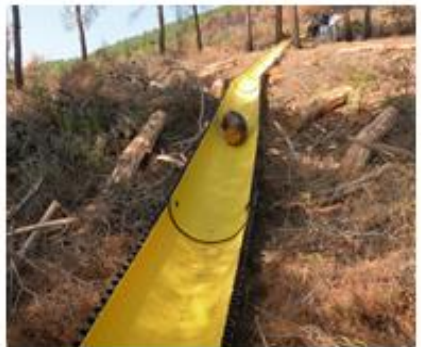

(c)

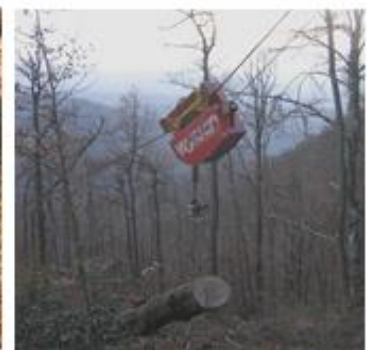

(d)

Figure 1. Primer forest transportation methods used in Turkey: a) Farm tractor, b) Skidder, c) Cable system, d) Chute system 
The ground slope is one of the most important limiting factors for the selection of optimum transportation methods. The stability of the forest soil is another constraint that affects the equipment selection. Soil stability reflects the mobility and potential soil impact of the mechanized equipment on forest surface (Akay et al., 2007). Therefore, alternative transportation methods should be systematically investigated by considering limiting factors such as terrain characteristics and surface soil features.

Transportation problems involving alternative solutions with various constraints can be addressed by using multi criteria decision support (MCDS) methods. In recent years, GIS tool integrated with MCDS models have been used to solve complex problems in the field of forestry (Pittman, 2003; Türk, 2011; Aydin and Eker, 2012). AHP is one of the widely used multicriteria decision-support methods used in forestry operations (Coulter et al., 2006) to solve complex decision problems. AHP approach, first modelled by Saaty (1977), searches for the optimal solution among a set of alternative options based on set of evaluation criteria.

In this study, GIS and AHP method was used to plan primer transportation of forest products. The method was implemented in İnegöl Forest Enterprise Directorate (FED) that has very rich forest resources and intensive forestry operations involving mechanized transportation methods.

\section{MATERIAL AND METHODS}

\subsection{Study Area}

The study area was Oylat Forest Enterprise Chief (FEC) in the border of İnegöl FED in Bursa, Turkey (Figure 2). The areal distribution of forest resources with respect to FECs located in the İnegöl FED is indicated in Table 1. The dominant trees in the study area were beech, yellow pine and black pine. The average elevation and ground slope were $1005 \mathrm{~m}$ and $30 \%$, respectively. The forest transportation methods available in the region included cable system, chute system, skidder, and farm tractor.

\begin{tabular}{|l|c|c|c|}
\hline FECs & $\begin{array}{c}\text { High } \\
\text { Forest }\end{array}$ & $\begin{array}{c}\text { Degraded } \\
\text { Forest }\end{array}$ & $\begin{array}{c}\text { Total } \\
\text { Forest }\end{array}$ \\
\hline Boğazova & 4173.50 & 286.00 & 4459.50 \\
Hayriye & 3426.50 & 586.00 & 4012.50 \\
İclaliye & 3842.00 & 880.00 & 4722.00 \\
İnayet & 3147.60 & 383.80 & 3531.40 \\
İnegö1 & 8912.00 & 2325.00 & 11237.00 \\
Mezit & 2899.00 & 177.00 & 3076.00 \\
Oylat & 4386.00 & 566.00 & 4952.00 \\
Tahtaköprü & 3636.50 & 204.50 & 3841.00 \\
Yenice & 6402.00 & 2123.20 & 8525.20 \\
Yenişehir & 7053.00 & 12320.00 & 19373.00 \\
Total & 47878.10 & 19851.50 & 67729.60 \\
\hline
\end{tabular}

Table 1.Forest resources in İnegöl FED (ha) (URL-1)

\subsection{GIS Database}

Primer transportation method of forest products was planned by using GIS integrated AHP methods by considering ground slope and soil type. To generate slope and soil layers, necessary data layers including forest management map, topographic maps, and geological map were obtained from İnegöl FED. The forest management map (1:25000) was used to generate land use map of Oylat FEC. Then, forest cover was produced by delineating the forested areas that are classified as production forest. Forest cover layer was the border of the study site in the GIS applications that were implemented by using ArcGIS 10.4.1.

The contour lines (with $10 \mathrm{~m}$ intervals) on topographical maps (1:25000) were used to generate Digital Elevation Model (DEM). Then slope map was produced based on DEM (10 x 10 $\mathrm{m})$. Then, slope map was reclassified into five classes according to IUFRO slope classification suggested for transportation operations (Gülci, 2014). In this study, slope map was divided into 4 classes: 1) Steep >50, 2) High 34-50\%, 3) Medium 21-33 $\%$, and 4) Gentle/Low $<21$. The geological map was used to produce soil type map $(10 \mathrm{~m} \times 10 \mathrm{~m})$ of the study area. In order to indicate stable and unstable soils, soil type map was classified into two classes.

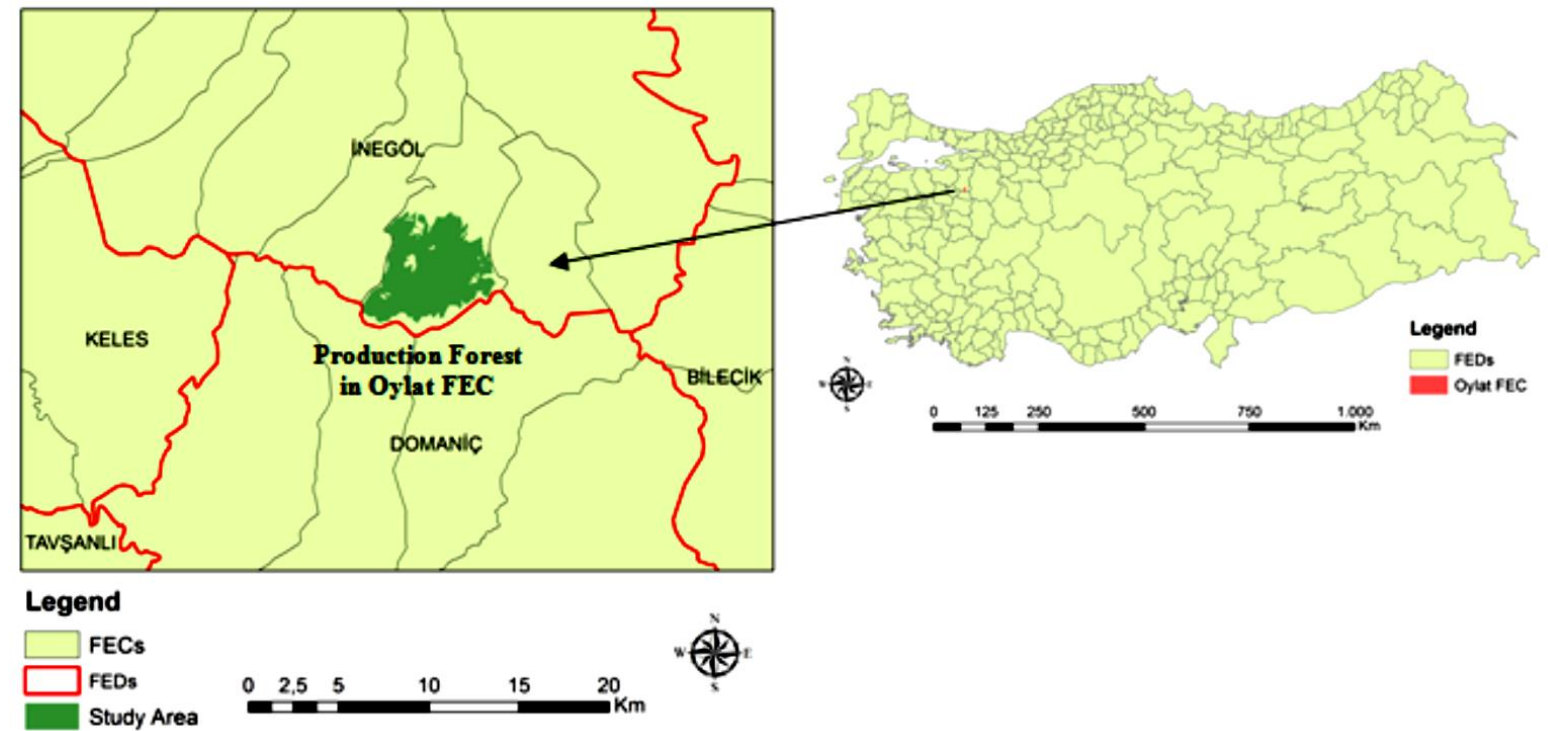

Figure 2. Study area 


\subsection{AHP Method}

Analytic Hierarchy Process (AHP) approach was used to develop optimum primer transportation plan (Figure 3). In the solution process of AHP, four alternative transportation methods (cable system, chute system, skidder, and farm tractor) were evaluated. The main criteria included terrain conditions (slope), and soil type (stability). A weight for each criterion was generated based on decision maker's pairwise comparisons. A numerical scale from 1 to 9 was used to measure the relative importance between two criteria (Table 2).

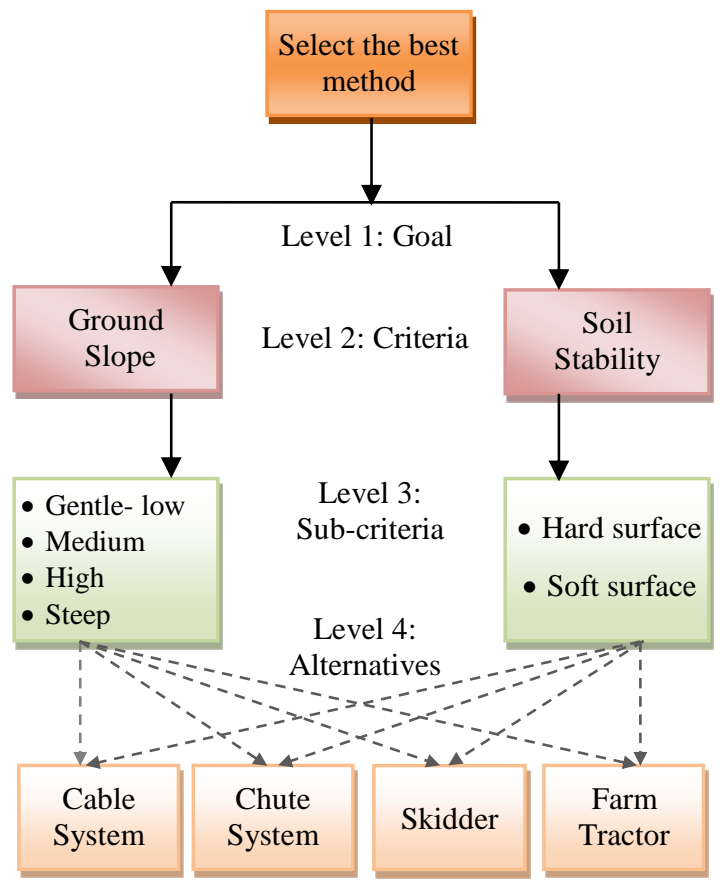

Figure 3. The hierarchy of AHP method

\begin{tabular}{|c|c|}
\hline $\begin{array}{l}\text { Importance } \\
\text { Scale }\end{array}$ & Definitions \\
\hline 1 & Equal importance \\
\hline 3 & $\begin{array}{l}\text { Weak importance of one over } \\
\text { another }\end{array}$ \\
\hline 5 & Essential or strong importance \\
\hline 7 & Demonstrated importance \\
\hline 9 & Absolute importance \\
\hline $2,4,6,8$ & $\begin{array}{l}\text { Intermediate values between the } \\
\text { two adjacent judgments }\end{array}$ \\
\hline
\end{tabular}

Table 2. The relative importance

For each alternative method, first the relative importance values among sub-criteria were evaluated. When the criterion is the more important, the higher score was given. The normalized pairwise comparison matrix was used to compute the weighted averages of the sub-criteria. Then, "Reclassify" tool under "Spatial Analyst" extension of ArcGIS 10.2 was used to assign weighted average values to the corresponding criteria.

The importance of main criteria was compared based on the importance scale. Finally, a score was assigned to each alternative transportation method based on the decision maker's pairwise comparisons. To control the consistency of the evaluations, the ratio of Consistency Index (CI) and Random Index (RI) were computed. The small value of this ratio $(<0.1)$ suggested that results drawn from the AHP method.

After consistency analysis, "extAhp 2.0" plug-in was used in ArcGIS 10.4.1 to combine the weighted averages of the criteria and determine the AHP score for each method. Finally, the optimum method with the highest score was found by a weighted sum of the scores with respect to all the criteria.

\section{RESULTS AND DISCUSSION}

\subsection{GIS Data Layers}

The areal distribution of land use types is indicated in Table 3. It was found that most of the study area was covered by forests (77.48\%), and followed by agricultural areas. The land use types and production forest (study site) were shown in Figure 4.

\begin{tabular}{|l|c|}
\hline Land Use Types & Area \\
\hline Production Forest/Forest & 77.48 \\
Agriculture & 19.42 \\
Open Areas (OA) & 1.87 \\
Residential Areas & 0.87 \\
OA/Stony Areas & 0.20 \\
Depots & 0.17 \\
\hline
\end{tabular}

Table 3. Areal distribution (\%) of the land use types

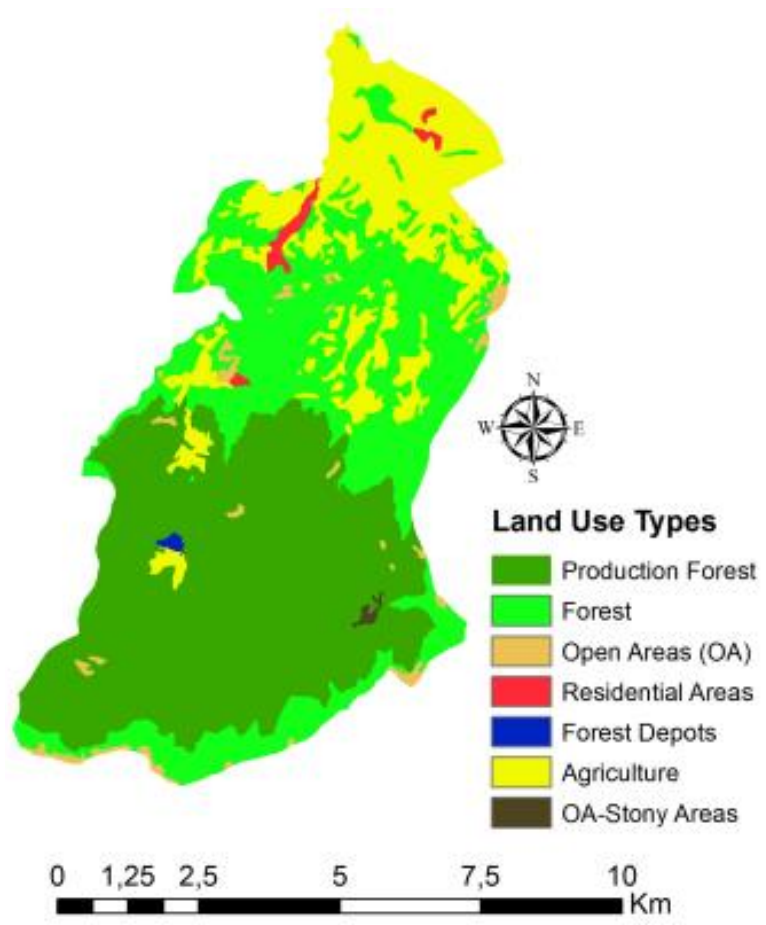

Figure 4. Land use types

The ground slope map indicated that $37 \%$ of the study area was on medium slope class, while $29 \%$ was on high slope class (Table 4, Figure 5). About 25\% of the area was classified as gentle and low slope classes, and rest of the area was on steep terrain.

The geological map was used to generate soil type map indicating stability of the surface soil (Figure 6). It was found that the soil surface was stable in $90.94 \%$ of the area, while it was unstable in the rest of the area. 


\begin{tabular}{|l|c|}
\hline Slope Classes & Area \\
\hline Gentle and low & 25.17 \\
Medium & 36.54 \\
High & 28.82 \\
Steep & 9.47 \\
\hline
\end{tabular}

Table 4. Areal distribution (\%) of slope classes

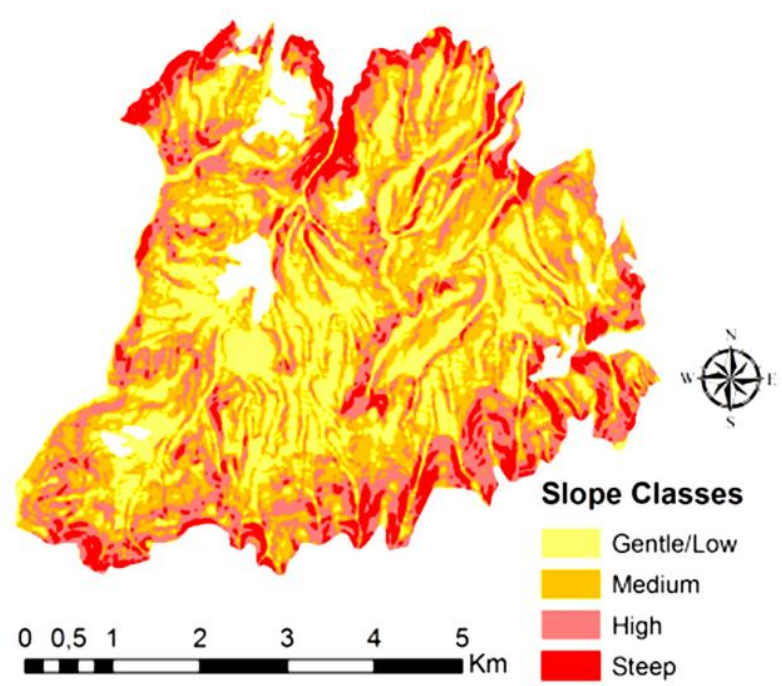

Figure 5. Slope map

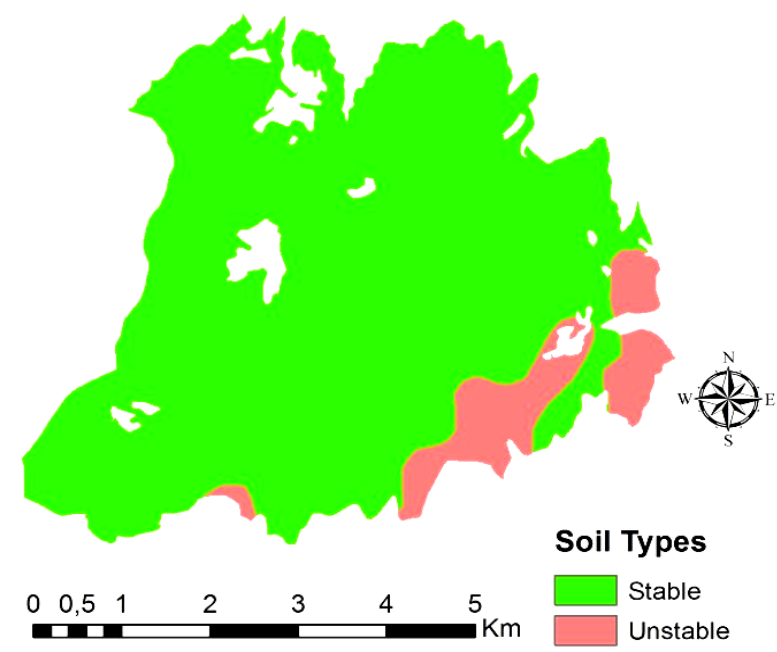

Figure 6. Soil type map

\subsection{AHP Results}

To compute the weighted values for the criteria and their subcriteria a pairwise comparison matrix was generated. The weighted values of slope (sub-criteria) for alternative transportation methods were indicated in Table 5. For steep terrain, the cable system was appropriate, while chute system was suitable for high slope classes. The skidder and farm tractor were more appropriate for medium and gentle/low slope areas, respectively.

For alternative methods, the weighted values of soil type were indicated in Table 6 . The cable system and chute system were suitable for unstable soil, while skidder and farm tractor were more appropriate for stable soil.

\begin{tabular}{|l|c|c|c|c|}
\hline $\begin{array}{l}\text { Slope } \\
\text { Classes }\end{array}$ & $\begin{array}{c}\text { Cable } \\
\text { System }\end{array}$ & $\begin{array}{c}\text { Chute } \\
\text { System }\end{array}$ & Skidder & $\begin{array}{c}\text { Farm } \\
\text { Tractor }\end{array}$ \\
\hline Gentle/low & 0.07 & 0.07 & 0.13 & 0.64 \\
Medium & 0.07 & 0.20 & 0.60 & 0.21 \\
High & 0.21 & 0.60 & 0.20 & 0.07 \\
Steep & 0.64 & 0.13 & 0.07 & 0.07 \\
\hline
\end{tabular}

Table 5. The weighted values of slope class

\begin{tabular}{|l|c|c|c|c|}
\hline $\begin{array}{l}\text { Soil } \\
\text { Types }\end{array}$ & $\begin{array}{c}\text { Cable } \\
\text { System }\end{array}$ & $\begin{array}{c}\text { Chute } \\
\text { System }\end{array}$ & Skidder & $\begin{array}{c}\text { Farm } \\
\text { Tractor }\end{array}$ \\
\hline Stable & 0.42 & 0.30 & 0.90 & 0.80 \\
Unstable & 0.58 & 0.70 & 0.10 & 0.20 \\
\hline
\end{tabular}

Table 6 . The weighted values of soil type

The weighted averages of the criteria were combined for the alternatives and the score for each transportation method was determined by using "extAhp 2.0" tool in ArcGIS 10.4.1. The result indicated that the most effective criterion was slope for cable system and chute system. The importance of soil was higher than slope for ground-based equipment (Figure 7-10). Table 7 indicates the weighted average values of criteria assigned to alternative transportation methods.

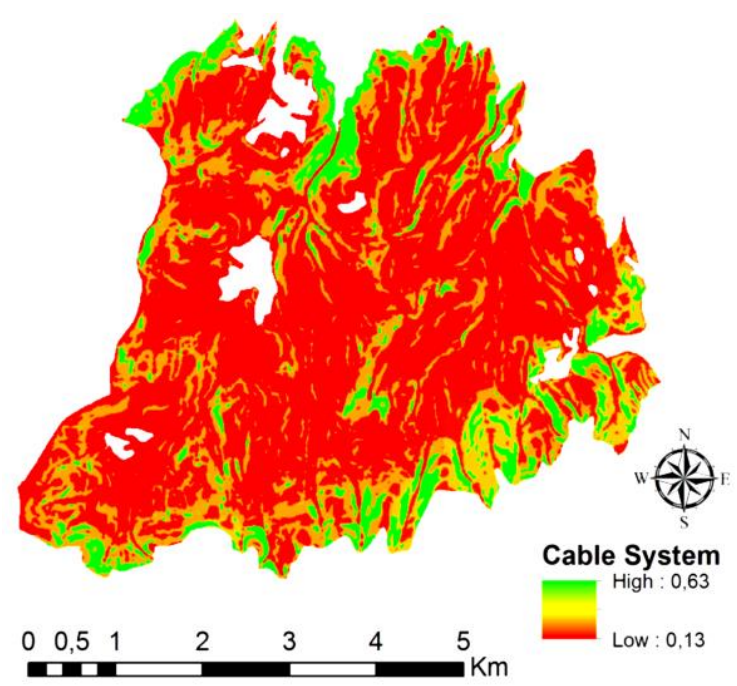

Figure 7. Cable system

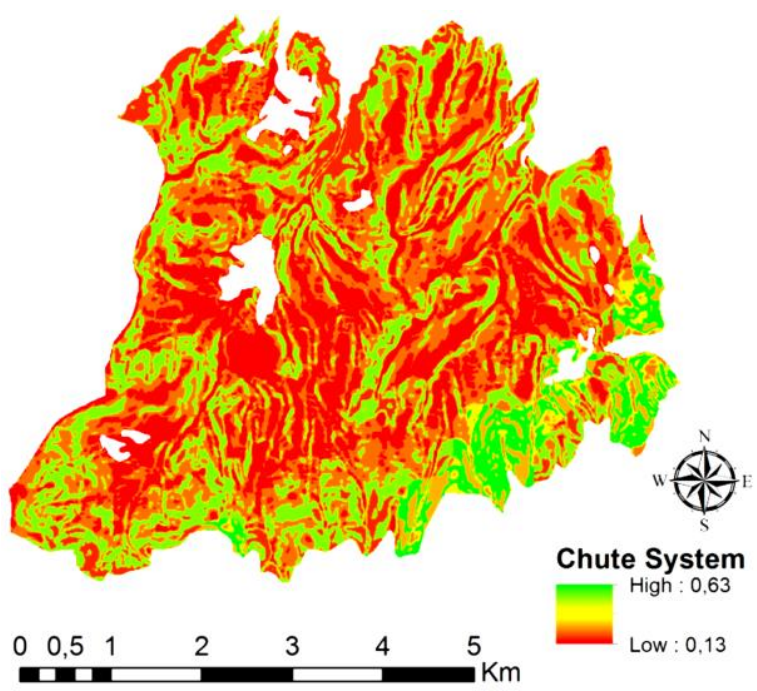

Figure 8. Chute system 


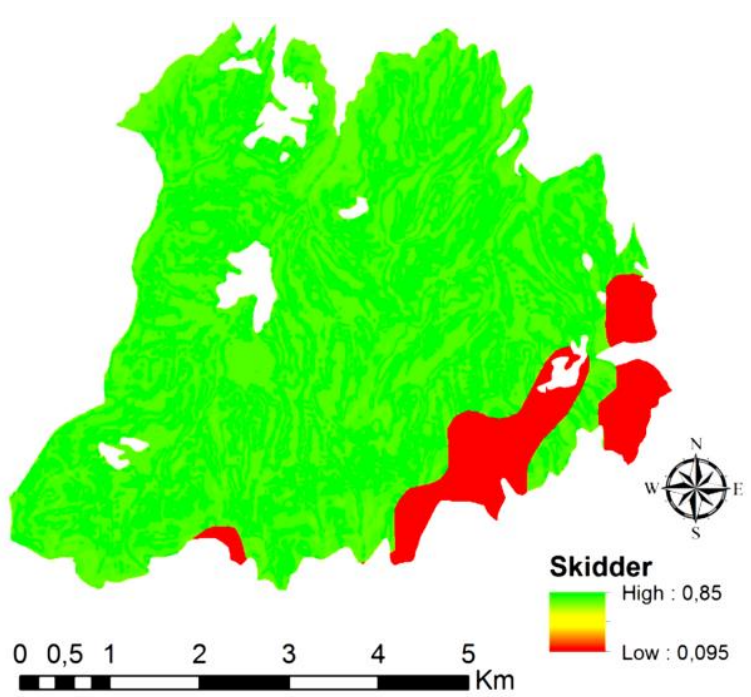

Figure 9. Skidder operation

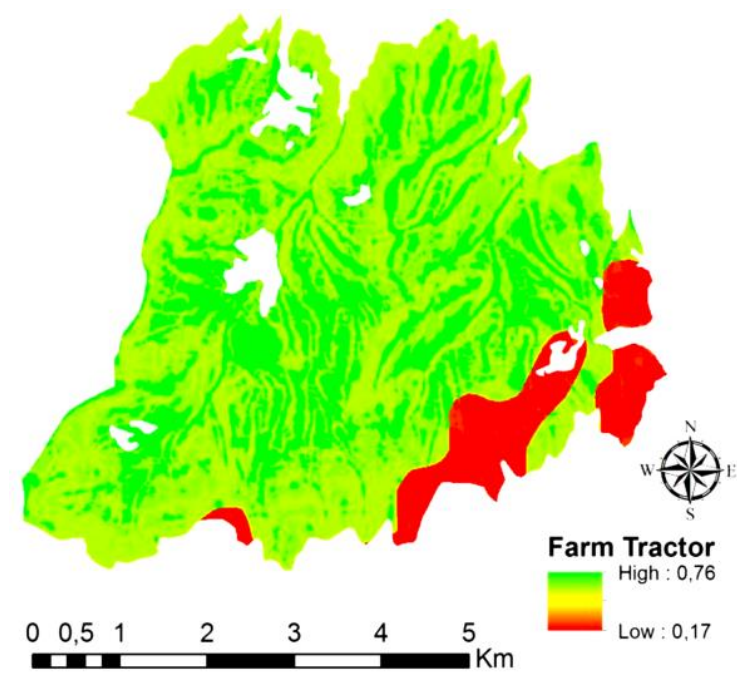

Figure 10. Farm tractor operation

\begin{tabular}{|l|c|c|c|c|}
\hline Criteria & $\begin{array}{c}\text { Cable } \\
\text { System }\end{array}$ & $\begin{array}{c}\text { Chute } \\
\text { System }\end{array}$ & Skidder & $\begin{array}{c}\text { Farm } \\
\text { Tractor }\end{array}$ \\
\hline Slope & 0.83 & 0.75 & 0.17 & 0.25 \\
Soil & 0.17 & 0.25 & 0.83 & 0.75 \\
\hline
\end{tabular}

Table 7. The weighted values of criteria

Table 8 indicates areal distribution of optimum transportation methods with the highest weighted average with respect to all the criteria. The results showed that skidder method was suggested as optimum method for $59.1 \%$ of the study area (Figure 11). The chute system was the second most favourable system $(25.17 \%)$ in the study area. Cable system and chute system were the optimal methods for $9.47 \%$ and $6.26 \%$ of the study area, respectively.

\begin{tabular}{|l|c|}
\hline Transportation & Area \\
Systems & 9.47 \\
\hline Cable System & 6.26 \\
Chute System & 59.10 \\
Skidder & 25.17 \\
Farm Tractor & \\
\hline
\end{tabular}

Table 8. The areal distribution (\%) of transportation methods

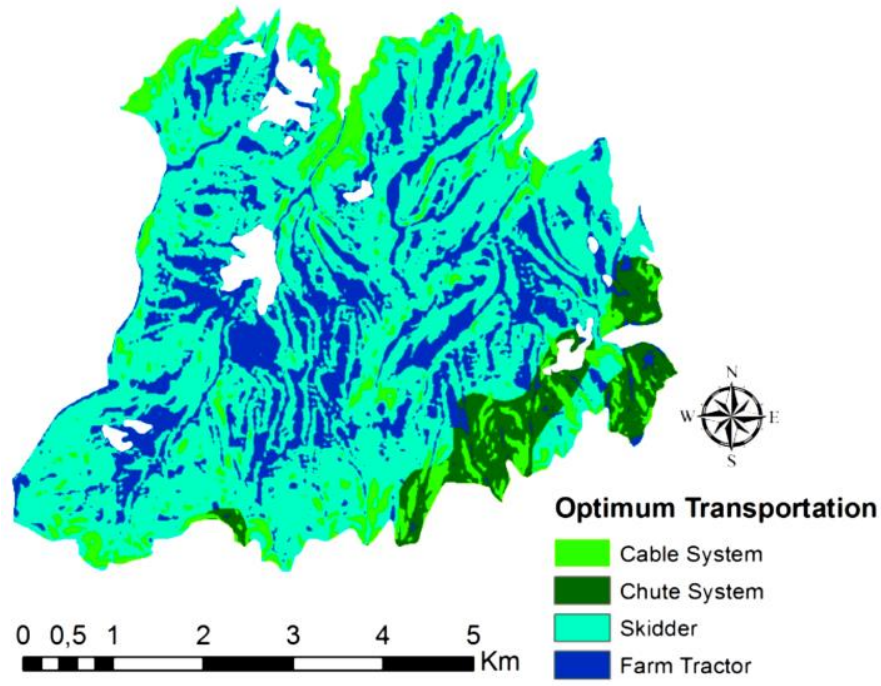

Figure 11. Optimum forest transportation map

\section{CONCLUSIONS}

Primer transportation of forest products is one of the most costly and time consuming forestry activities in timber extraction. Also, unplanned transportation operations may cause ecological damages, especially soil disturbance. In order to minimize these potential damages and ensure sustainability of forest ecosystem, primer transportation activities should be well planned by considering productivity and ecological effects of alternative transportation methods. The advanced features of Geographical Information System (GIS) can assist decision makers to solve such complex transportation problems. This study aimed to develop forest transportation plan by using GIS integrated Analytical Hierarchy Process (AHP) method. In the solution process, ground slope and soil type were main criteria while alternative methods were cable system, chute system, skidder, and farm tractor. The results indicated that skidder operation is the most convenient primer transportation system in the study area. The second most suitable method was other ground-based transportation method. The usage of cable system was limited by the forest areas with steep slope. Chute system was the least appropriate transportation method in the study area. It can be concluded that GIS and AHP methods can be effectively used forest transportation planning.

\section{ACKNOWLEDGEMENTS}

This study was supported by Scientific Research Project Unit of Bursa Technical University, with the project number 171L16.

\section{REFERENCES}

Akay, A.E., Erdaş, O., 2007. Estimating Rut Depth During Skidding with a Rubber-Tired Skidder. SDU Faculty of Forestry Journal, (1), pp. 49-57.

Akay, A.E., Yuksel, A., Reis, M., Tutus, A., 2007. The Impacts of Ground-based Logging Equipment on Forest Soil. Pol. J. Env. Stud. 16(3), pp. 371-376.

Akay, A.E., Yenilmez, N., 2008. Harvesting machines used in forest operations in North America. Chamber of Forest Engineers, Forest Engineering Journal, 45(1-3), pp. 24-28. 
Akay, A.E., Özkan, D., Bilici, E., 2016. Assessing Productivity and Work Safety of a Mechanized Logging Operation. The International Forestry Symposium (IFS 2016). 7-11 December, Kastamonu, Turkey.

Aydın, A., Eker, R., 2012. Preparation of Slope Maps Using GIS Based Fuzzy Membership Model and Comparison with Classical Method: A Case Study of Avalanche Risk Assessment. KSU Eng Sci Journal, Special Issue, (1), pp.206212.

Coulter, E.D., Coakley, J., Sessions, J., 2006. The Analytic Hierarchy Process: A tutorial for Use in Prioritizing Forest Road Investments to Minimize Environmental Effects. International Journal of Forest Engineering. 17(2), pp. 51-69.

Çankal, H., 2013. Productivity and environmental evaluation of chute system used in log production Msc. thesis, KSU, Faculty of Forestry, Kahramanmaraş, Turkey. 39 p.

Gülci, N. 2014. Researches on precision forestry in forest planning. Ph.D. thesis, KSU, Kahramanmaraş. 264 p.

Gülci, N., Akay, A.E., Erdaş, O., Acar, H.H., Wing, M.G., 2016. Controlled sliding of logs downhill by chute system integrated with portable winch and synthetic rope. Journal of the Faculty of Forestry Istanbul University, 66(1), pp. 256-263.

Pittman, S.D., 2003. Elements of Hierarchical Planning in Forestry: A Focus on the Mathematical Model. Proceedings of the Second International Precision Forestry Symposium, 15-17 June, Seattle, Washington, USA.

Saaty, T.L., 1977. A scaling method for priorities in hierarchical structures. J Math Psychol. 15, pp.234-281.

Türk, Y. 2011. The Optimization of Skid Trails Network for Extracting of Industrial Wood Based Forest Products by Farm Tractors in Forestry. Ph.D. thesis, KTU, Trabzon. 159 p.

URL-1. Forest Resources, General Directorate of Forestry, Bursa Regional Directorate of Forestry, http://bursaobm.ogm.gov.tr/inegolOIM/Lists/Orman\%20Varligi /AllItems.aspx (Last visited: 01/08/2017)

Yilmaz, M., Akay, A.E., 2008. Stand Damage of a Selection Cutting System in an Uneven Aged Mixed Forest of Çimendagi in Kahramanmaras-Turkey. International Journal of Natural and Engineering Sciences, 2(1), pp. 77-82. 